\title{
Banded leaf and sheath blight: A menacing disease of maize (Zea mays L.) and its management
}

\author{
Sorabh Chaudhary ${ }^{* 1}$, Sushma Sagar ${ }^{1}$, Akash Tomar $^{2}$, R. S. Sengar ${ }^{1}$ and Mukesh Kumar ${ }^{1}$ \\ ${ }^{1}$ Department of Agriculture Biotechnology, College of Agriculture, S.V.P. University of Agriculture \& Technol- \\ ogy, Meerut-250110 (Uttar Pradesh), INDIA \\ ${ }^{2}$ Department of Recombination Techniques, College of Biotechnology, S.V.P. University of Agriculture \& Tech- \\ nology, Meerut-250110 (Uttar Pradesh), INDIA \\ *Corresponding author. E- mail: sorabh.gene@gmail.com
}

Received: November 20, 2015; Revised received: April 30, 2016; Accepted: July 18, 2016

\begin{abstract}
Maize (Zea mays L.) crop is attacked by number of fungal, bacterial and viral diseases, out of which banded leaf and sheath blight (BLSB) caused by anastomosis group 1-IA of Rhizoctonia solani f. sp. sasakii Exner. is one of the most widespread and destructive disease of maize in Southeast Asian countries. The occurrence of this disease has also been reported from other parts of the world, which causes significant yield loss up to $100 \%$. $R$. solani can survive in the soil for several years and able to infect plants belonging to more than 32 families, including many economically important monocots and dicots plants. The severity of the disease favoured by humid weather with temperature around $28^{\circ} \mathrm{C}$, poses challenge to maize growers due to its soil borne nature and lack of resistance cultivars. It is indicated that none of the disease management approaches are effective against BLSB. Banded leaf and sheath blight is difficult to control through either fungicide or crop rotation alone. A number of quantitative trait loci (QTLs) controlling BLSB have been identified that would help the development of maize hybrids resistance to this disease. Management of BLSB requires an integrated approach based on the knowledge of each stage of the disease and molecular aspect of maize defence responses against $R$. solani. Mention conclusion statement and novelty of the work. The present review summarizes consolidated information on distribution, yield loss, symptoms, pathogen life cycle, epidemiology, genetic structure of the pathogen population, molecular aspect of pathogenicity and its integrated management through cultural, biological, chemical and genetic means. The consolidated knowledge presented in this review should help better disease management and reduce crop yield loss due to banded leaf and sheath blight pathogen.
\end{abstract}

Keywords: Banded leaf and sheath blight, Biological control, Genetic variability, Rhizoctonia solani f. sp. sasakii, Zea mays

\section{INTRODUCTION}

Maize (Zea mays L.) is one of the most important cereal crops in the world agricultural economy as food, feed and industrial products. As compare to rice and wheat, maize contains approximately $72 \%$ starch, $10 \%$ protein, and $4 \%$ fat, supplying an energy density of $365 \mathrm{Kcal} / 100 \mathrm{gm}$ (Nuss and Tanumihardjo, 2010). Being a $\mathrm{C}_{4}$ cereal crop, it is cultivated widely throughout the world and has the highest production among all the cereals. It is estimated that in 2014, the total world production of maize was 1021.6 million tons (FAO, 2015), with the United States, China, and Brazil harvesting $35 \%, 24 \%$, and $8 \%$ of the total production of maize respectively. India ranked $6^{\text {th }}$ with the total maize production 23.7 million tons and share $2.3 \%$ of the total worldwide maize production. In India, maize is the third most important cereal crop after rice and wheat, grown in a wide range of environments extending from extreme semi-arid to sub-humid and humid regions. Traditional maize growing areas, includes Bihar, Madhya Pradesh, Rajasthan, Uttar Pradesh and
Gujarat, whereas, non-traditional maize areas are Karnataka and Andhra Pradesh (Joshi et al., 2005).

Despite very high yield potential of maize, one of the major deterrents to high grain yield is its sensitivity to several diseases. From different parts of the world, about 112 diseases of maize have been reported, of these, 65 are known to occur in India (Saxena, 2002). Seed rot and seedling blight, leaf spots and blights, downy mildews, stalk rots, banded leaf and sheath blight, and smut and rots are the most important diseases of maize crop (Hafiz, 1986). Among different fungal diseases affecting maize production, banded leaf and sheath blight (BLSB) induced by Rhizoctonia solani $\mathrm{f}$. sp. sasakii causes significant gain yield loss from $11 \%$ to $40 \%$, even to $100 \%$ on some cultivars in some warm and humid regions, where the conditions are favourable for the pathogen (Madhavi et al., 2011, Izhar and Chakraborty 2013; Gao et al., 2014).

The pathogen: The causal agent of banded leaf and sheath blight (BLSB) is Thanatephorus sasakii (Shirai) Tu and Kimbrough (St. Imp. Rhizoctoniz solani Kühn ISSN : 0974-9411 (Print), 2231-5209 (Online) All Rights Reserved @ Applied and Natural Science Foundation www.jans.ansfoundation.org 
f. sp. sasakii Exner). This is one of the most wide spread, destructive and versatile pathogen found in most parts of the world and infecting a vast range of host plants, including maize causing seed decay, damping -off, stem canker, root rot, aerial blight, and seed or cob decay (Ogoshi, 1987). Previously, the causal agent of maize sheath blight was thought to be the anastomosis group (AG) 1 of multinucleate Rhizoctonia solani Kühn (teleomorph: Thanatephorus cucmeris (A. B. Frank) Donk), which is a soil- born fungal pathogen with a wide host range. Recently, however, some binucleate isolates belonging to AG-Ba and AG-A of group (AG) (Xia et al., 2008; Zhou et al., 2012) and one uninucleate isolate (Zhou et al., 2015) of Rhizoctonia spp. have also been identified as pathogens of maize sheath blight. Caesar et al. (2010), Fang et al. (2013) and Zhou et al. (2016) observed the variation in virulence of pathogenic Rhizoctonia spp. and found that there was significant difference in virulence among the pathogenic Rhizoctonia isolates, with multinucleate isolates the greatest, binucleate isolates moderate and uninucleate Rhizoctonia isolate the lowest.

Distribution : This disease was first reported from Sri Lanka in 1927 as Sclerotial disease (Bertus, 1927), and subsequently recorded from Malaysia, under the name of 'banded sheath rot', in the Philippines as 'banded sclerotial disease' and as 'summer sheath blight' in Japan (Wiltshire, 1956). This disease has also been reported in Germany, USA, Nigeria, Venezuela, Sierra Leone, Ivory Coast and England. BLSB is recognized as a serious impediment to maize production in China, South Asia and Southeast Asia (India, Sri Lanka, Indonesia, Cambodia, Bangladesh, Pakistan, Nepal, Myanmar, Japan, Malaysia, Thailand, Laos, Vietnam, Taiwan, and Korea). Surprisingly, in China, yield losses close to $100 \%$ have been attributed to BLSB (Singh and Shahi, 2012). In India, the disease has been reported from states of Himachal Pradesh, Uttar Pradesh, Haryana, Punjab, Madhya Pradesh, Rajasthan, West Bengal, Meghalaya, Assam and Orissa (Rani et al., 2013).

Taxonomy Classification: The genus concept Rhizoctonia was first described by De Candolle in 1815 (Sneh et al., 1991). Rhizoctonia solani is a genetically diverse group of fungi with more than 100 species (Anderson, 1982; Adam, 1988; Binder et al., 2005), that attack all known crops. A method based on anastomosis groups (AGs) has been used for its identification and classification (Parmeter et al., 1969; Ogoshi, 1987). Among the 14 AGs of multinucleate Rhizoctonia, AG1 comprises many plant-pathogenic isolates recovered from a range of hosts. AG1 isolates have been divided into three subgroups based on host, symptoms and cultural characteristics: AG1-IA (sheath blight); AG1-IB (web blight); and AG1-IC (dampingoff). However, the host range of AG1-IA and AG1-IB overlap (Ogoshi, 1987; Sneh et al., 1991; Liu and Sinclair, 1993a). Although isolates of AG1 (includes
Rhizoctonia solani causing BLSB) have been reported worldwide (Ogoshi, 1987).

Cultural Characteristics: The young colonies produced by the fungus were fast growing and formed silky white colonies on Potato Dextrose Agar (PDA) medium; growth optimum at 25 and $30^{\circ} \mathrm{C}$; which gradually lost their lustre and became dull. Mycelium often is colourless at young stage, while turns to light brown as it matures (Ahuja and Payak, 1985; Sivakumar et al., 2000). Microscopic studies of hyphae revealed, it as multinucleate; branching near distal septum of cells in young vegetative hyphae; formation of septum in the branch near the point of origin; construction of branch; dolipore septum; no clamp connection; no conidium; sclerotium not differentiated in rind and medulla and no rhizomorph (Ogoshi, 1975; Ahuja and Payak, 1988). Sclerotia of $R$. solani were produced abundantly in culture, typically 1-5 $\mu \mathrm{m}$ diameter spherical and dark brown to black in colour (Akhtar et al., 2009).

Symptoms, disease development and epidemiology: The pathogen affects all aerial parts of the maize plant except tassel. The disease manifests itself on leaf, leaf sheaths, stalks and ears as leaf blight, stalk lesion or rind spotting and stalk breakage etc. It was reported that BLSB disease appears at pre-flowering stage on 30 to 40 day-old maize plants, but infection can also occur on young plants which may subsequently result in severe blighting and death of apical region of growing plant (Saxena, 2002). The disease symptoms on leaves as irregularly globular to elongated lesions which appears as water-soaked areas. The affected areas appear bleached, soon they become straw colored and necrotic (Ahuja and Payak, 1982). The lesions enlarge rapidly resulting in discoloured areas alternating with dark bands, apparent on lower leaves after 7-8 days (Rani et al., 2013).

The symptoms are more common on sheaths than leaves. A short of wave pattern of disease advancement can be seen not only on leaves but also on sheaths and husk leaves. The disease manifests itself on leaf, leaf sheath, stalks and ears as leaf and sheath blight, stalk lesions or rind spotting and stalks breakage, clumping and cracking of styles and horseshoe shaped lesions with banding of caryopses resulting in ear rots (Knight and Bunil, 1964; Sharma, 1999). In early stages marginal chlorosis and rooting of laminae proceed inwardly, later as the infection becomes older numerous sclerotial bodies are also seen (Saxena, 1997). Buddemeyer et al. (2004), observed that R. solani caused round to elliptical, yellow to tan or black lesions on seminal crown and brace roots of maize cultivars. Depending on disease severity, crown roots of maize plants were completely rotten and affected plants lodged. Typical BLSB symptoms were observed as small purplish brown lesion or greenish olive brown large continuous patches on leaf sheath and pale olive brown lesions on stalk as well as rotting of ears 
(Akhtar et al., 2009).

The fungus is capable of infecting maize plants in all the stages of crop growth right from seedling to maturity. $R$. solani survive in the soil and on infected crop debris as sclerotia or mycelium. Sclerotium serves as primary inoculum. The fungi spread by irrigation, movement of contaminated soil and infected plant debris. At the onset of growing season, in response to favourable humidity and temperature $\left(15\right.$ to $\left.35^{\circ} \mathrm{C}\right)$, the fungal growth is attracted to rapidly growing seedlings and water soaked seed coats by chemotropic stimulants released by growing plant cells and decomposing plant residue. Secondary spread of this disease occurs by contact of diseased leaves or sheath with healthy plants. High relative humidity $(90 \%)$, an optimum temperature about $28^{\circ} \mathrm{C}$, and rain fall in the first week of infection significantly favours the development and spread of disease. Disease development and spread becomes slow, if the relative humidity goes below $70 \%$ (Sharma, 2005). Crop damage is caused by loss of photosynthetic leaf area due to foliar infection and stalk rot which lead to crop lodging (Lu et al., 2012). Sheath blight reduced the breaking resistance of lower internodes and consequently resulted in poor lodging resistance $(\mathrm{Wu}$ et al., 2012). The maximum damage is caused when ears of maize are infected (Ahuja and Payak, 1982).

Economic Importance: The disease causes a considerable reduction of high yielding maize varieties, resulting in premature death, stalk breakage and ear rot. In India, Singh and Sharma (1976), have estimated $40.5 \%$ reduction in maize grain yield with $71 \%$ of BLSB disease index, whereas Lal et al. (1980) estimated loss in grain yield ranging from 23.9 to $31.9 \%$ at disease score levels ranging from 3.0 to 5.0 in ten cultivars. Lal et al. (1985), suggested that due to BLSB maize grain yield loss vary to the extent of over $90 \%$. In Guangxi province in South China, maize yield losses of 87.5 and $57.8 \%$ have been determined under natural conditions in the hybrids Luya 13 and Guiding planted at Bao Qiao and Chen Xiang countries (Sharma, 2005). Summer and Minton (1989), planted maize in infested and non-infested soils with high and low inoculum levels, estimated yield reduction of 42 and $8 \%$ in soils infested with high inoculum level, while the same was 17 and $1 \%$ under low inoculum level for a period of three years in USA. Tang et al. (2004), reported that BLSB caused 0-60\% loss in maize grain yield under natural conditions. However, the magnitude of grain loss may reach $100 \%$, if the ear rot phase of the disease predominated (Huang et al., 2007).

Host Range: The pathogen has wide host range and infects plants belonging to over 32 families in 188 genera. Isolates of $R$. solani causing BLSB disease in maize infected members of Gramineae (Cynodon dactylon, Oryza sativa, Saccharum officinarum and Sorghum bicolor), Leguminosae (Arachis hypogaea, Glycine max, Pisum sativam and Vigna radiate) and So- lanaceae (Lycopersicum esculentum and Solanum tuberosum) (Baruah and Lal, 1981). In artificial inoculations it infects a number of crop plants belonging to families Poaceae, Papilionaceae and Solanaceae: Paspalum serobiculatum, Pennisetum americanum, $P$. purpureum, Setaria italic, Panicum miliaceum, Coix lachrymal-jobi, Echinochloa frumentacea, Zea mays, Zea Mexicana, O.sativa, S. officinarun, S. bicolor), (Ahuja and Payak, 1988; Trivedi and Rathore, 2006). Maize has also been infected by strain of $R$. solani from rice, sugarcane, arrow root and some grasses (Ahuja and Payak, 1985). Rice and maize isolates are, however, indistinguishable on the basis of cross inoculation tests, host range, virulence, number of nuclei per hyphal cell, and other morphological characters including pathogenicity. Comparison studies on cultural and morphological characteristics of $R$. solani isolates from rice, maize, sugarcane, and sorghum revealed that maize and rice are similar than those isolates of sugarcane and sorghum (Saxena, 1997).

Mechanism involved in penetration of host tissue: $R$. solani can infect underlying tissues either through mechanical penetration by means of force or through utilizing natural openings and wounds (Parmeter, 1970; Back et al., 2002). The infection starts when mycelia or hypae of the fungus starts to grow towards a suitable host as a result of attracting chemical exudates, e.g., amino acids, sugars, organic acids and phenols, from the plants (Keijer, 1996a). After the first contact, loose and still unattached hypha starts to grow over the plant and within a few hours the hypha flattens and directional growth over the epidermal cells is initiated, forming T-shaped hyphal branches that can give rise to hyphal aggregates known as infection cushions (Keijer, 1996a; Dodman and Flintje, 1970). Fine infection pegs develop from the infection cushion, enable the fungus to minimize the force needed for penetration. However, also the production of lobate appressoria was observed on rice (Marshall and Rush, 1980). After a peg has penetrated, it continues to grow between the cuticle and the epidermal wall. Finally the cuticle and epidermal wall are penetrated, and the infectious organs may extend growth into the cell lumen (Demirci and Döken, 1998). Penetration is established by using hydrostatic pressure, even though degrading enzymes such as cutinases (Baker and Bateman, 1978), pectinases (Bertagnolli et al., 1996; Jayasinghe et al., 2004) and xylanases (Peltonen, 1995), are most probably also involved in infection and penetration. The production of endopectinlyase has been reported to be associated with the tissue degradation in later stage of infection (Gonzãlez-Garcia et al., 2006). Necrotic lesions on epidermal tissue of shoots, roots and stolons or as damping-off of the young seedlings can be seen, when fungus starts to grow inside the host and degrading the tissue (Demirci and Döken, 1998).

The fungus may also utilize natural openings viz. sto- 
mata on stems, cotyledons and leaves or lenticels as entry portals to plant tissue. Wounds can also be used as entry portals, but penetration usually does not occur solely via wounds. The growing hypha first spread and fill out the wound with densely packed hyphae before penetrating into healthy tissues without the formation of infection structure (Parmeter, 1970; Back et al., 2002). Plant defence mechanisms may stop the fungal infection at the following establishment stages of $R$. solani: a) attachment of hypha to plant surface, b) formation of infection structure, c) penetration of infection pegs, d) continue invasion of penetration hyphae can be stopped by hypersensitive reaction (Parmeter, 1970; Demirci and Döken, 1998).

Genetic structure of the $\boldsymbol{R}$. solani population: Genetic diversity in $R$. solani AGI-IA population is important for understanding its ecology, pathology, and host specificity. Therefore, by accessing the genetic variability within and among various populations of this phytopathogenic fungus will be useful in disease management. Isozyme and DNA analysis have advanced our understanding of the structure of $R$. solani populations. These molecular tools have easily and distinctly grouped $R$. solani into subgroups of an AG. Isolates of AG1-IA have been subject of different diversity and population studies in which variation has been measured using intra and extracellular enzymes and proteins (Liu and Sinclair, 1993b; Matsuyama et al., 1978; Neeraja et al., 2002a), and various fatty acids (Stevens Johnk and Jones, 1994), as well as various molecular techniques such as restriction fragment length polymorphism (RFLP) (Banniza et al., 1999; Rosewich et al., 1999), amplified fragment length polymorphism (AFLP) (Fiers et al., 2011; Taheri et al., 2007), repetitive element PCR (Rep-PCR) (Linde et al., 2005), simple sequence repeat polymerase chain reaction (SSR-PCR) or microsatellites (Banniza and Rutherford, 2001; Bernardes-De-Assis et al., 2009; Gonzalez-Vera et al., 2010), inter simple sequence repeats (ISSR) (Khodayari et al., 2009), analysis of sequence variation in ribosomal DNA (rDNA) (Fenille et al., 2003; Wang et al., 2015) and random amplified polymorphic DNA (RAPD) markers (Neeraja et al., 2002 b; Gad et al., 2013; Susheela and Reddy, 2013; Chikara et al., 2015). In a population genetic diversity study of $R$. solani from India that was based RFLP and Rep-PCR, results were consistent with small genetic distances among populations and high levels of gene flow (Linde et al., 2005).

Despite these studies, genetic variability within populations, particularly among isolates of different ISGs of $R$. solani AG1 infecting maize is poorly known. In particular, pathogen populations should be monitored to determine if new genotypes have been introduced into a region. However, understanding of disease epidemiology, host-pathogen interaction, and subsequently successful management of sheath blight dis- ease is really dependent on our knowledge concerning variability of the pathogen populations and the factors affecting genetic structure of these populations.

Molecular aspect of pathogenicity: Currently, molecular aspects of $R$. solani pathogenicity involved in maize leaf sheaths infected by BLSB are poorly known. The lack of molecular information on pathogenicity can be related to the relatively large genome size of the pathogen (Cubeta et al., 2009). R. solani isolates have at least 11 chromosomes ranging in size from 0.6 to $6 \mathrm{Mb}$ (Keijer et al., 1996b). At present, the genome sequences of AG-IA (Zheng et al., 2013), AG1-IB (Wibberg et al., 2013), AG3 (Cubeta et al., 2014), and AG8 (Hane et al., 2014) are available. The genome sizes ranges from 36.9 Mb (AG1-IA, 10,489 gene models), 39.8 Mb (AG8, 13,964 gene models), 47.6 Mb (AG1-IB, 12,422 gene models) to $51.0 \mathrm{Mb}$ (AG3, 12,726 gene models). The resulting databases will allow the comprehensive analysis of developmental processes that are characteristic of this fungus, including the molecular nature of pathogenicity. DNA databases support analysis of the fungal transcriptome, proteome, and metabolome.

Fungi inevitably respond to extracellular signals or stimuli via a wide array of transduction pathways for pathogenicity. One of the most studied pathways in the filamentous fungi is the signalling cascade mediated by membrane-bound heterotrimeric $\mathrm{G}$ proteins, composed of $\mathrm{G} \alpha$ from $\mathrm{G} \beta$ and $\mathrm{G} \gamma$ subunits (Li et al., 2007; Wendland, 2001). The $\mathrm{G} \alpha$ subunit containing intrinsic GTPase activity is the key step in controlling the cellular response via the $G$ protein signal transduction pathway. Upon receiving extracellular stimuli, a G proteincoupled receptor (GPCR) interacts with the G protein, inducing replacement of GDP in the G $\alpha$ subunit by GTP which leads to dissociation of $\mathrm{G} \alpha$ from $\mathrm{G} \beta$ and $\mathrm{G} \gamma$ subunits. The released $\mathrm{G} \alpha$ subunit becomes activated and in turn cyclase, phospholipase, ion transporters, and mitogen activated protein kinase (MAPK) involved in numerous biological processes like regulation of hyphal morphogenesis, infection structure formation, sclerotium formation, regulation of mating, sporulation and spore germination including pathogenicity (Neves et al., 2002). Charoensopharat et al. (2008), demonstrated the function of the $\mathrm{G} \alpha$ subunit gene, Rgal, in the rice sheath blight pathogen by target gene disruption and found that disruption of Rgal led to decreased vegetative growth and pathogenicity of the sheath blight pathogen $R$. solani. The Rgal disruptant showed altered colony morphology, also the sclerotia formation ability of the disruptant was completely lost. Similar results have been observed for the genes encoding $\mathrm{G}$ protein subunits in other phytopathogenic fungi, such as gpa3 in Ustilago maydis (Regenfelder et al., 1997), cpgl in Cryphonectria parasitica (Gao and Nuss, 1996), and fgal in Fusarium oxysporum (Jain et al., 2002).

Zheng et al. (2013), analysed the genome of $R$. solani 
AG1 IA isolate and predicted the likely genetic requirements for the necrotrophic phytopathogen to invade and colonize the rice plant. They concluded that necrotrophy does not require a large number of carbohydrate active enzymes (CAZymes) and secondary metabolites during infection, at least for $R$. solani AG1 IA, which mainly utilizes key pathogenic glycoside hydrolase (GHs) and genes. The novel divergent elements, such as G $\alpha$ proteins, GPCRs in MAPK signalling pathway, are dedicated to the exclusive parasitic lifestyle and regulate nutrition, reproduction and pathogenicity in the signal transduction pathway. Therefore, they hypothesized that $R$. solani AG1 IA pathogenesis includes key GHs, secondary metabolites and diverse effectors to supress the host defence at the early infection stage. HR and the plant defence can then be activated, which is followed by the progressive expression of specific genes encoding degradationassociated enzymes to damage the rice plant.

Genetics of resistance to BLSB: To date, there are very limited sources of germplasm available which can give high level of tolerance over locations under different environments. Hybrids developed through crossing of tolerant inbred lines show inconsistent level of resistance to this disease, under highly epiphytotic conditions. This may be attributed to inadequate knowledge about mode of inheritance of resistance, genotype $\times$ environment interactions for resistance and possible presence of different races. Vimla et al (1988), used combining ability analysis for resistance to BLSB and concluded that both general and specific combining abilities varied significantly for controlled disease resistance but general combining ability variance was predominant. They also identified inbred line CM104 as the most promising combiner for resistance. Kumar and Singh (2002), studied inheritance of resistance to BLSB on the basis of the analysis of 10 crosses. Eight crosses were made between two resistant (CM104 and CML1) and four susceptible inbred line, one cross each was made between resistance $\times$ resistance and susceptible $\times$ susceptible lines. The BLSB reaction in F2 and backcrosses involving CM104 and susceptible line suggested that resistance in CM 104 was controlled by Duplicate dominant genes while crosses of CML1 showed dominance and recessive interaction.

Recently, genetic and molecular studied on the BLSB and pathogens have been reported in maize (Li et al., 2009; Liu et al., 2011; Zhang et al., 2012). These studies revealed that resistance to BLSB is a typical quantitative trait controlled by polygenes and three significant quantitative trait loci (QTL) located on chromosome 2, 6, and 10 to be responsible for resistance to BLSB respectively (Campbell et al., 2002; Chen et al., 2000; Zhang et al., 2006). The identification of QTL for resistance to BLSB is considered as an effective tool in development of disease resistant maize hybrid. The information generated from mapping resistance genes can be used in marker assisted selection (MAS) programmes for development of BLSB resistant lines (Singh and Shahi, 2012). In an experiment conducted by Asea et al. (2012), results indicate that molecular markers linked to target rQTL can facilitate pyramiding resistance to multiple diseases during early generation of pedigree selection. Zhao et al (2006), screened a mapping population consisting of $229 \mathrm{~F} 2$ individuals, derived by crossing inbreds R15 (resistance) with 478 (susceptible), against $R$. solani at two locations. They constructed a genetic linkage map, containing 146 single sequence repeat (SSR) markers, on the basis of composite interval mapping, and identified 11 QTLs for resistance to BLSB located on chromosomes 1, 2, $3,4,5,6$, and 10. But only four QTLs located at chromosomes 2, 6, and 10 were identified across both locations. Lin et al. (2008) analysed digenic epistatic and QTL $\times$ environment interactions for resistance to BLSB and detected 17 QTLs including 12 pairs of digenic epistatc QTLs. These QTLs were distributed on seven chromosomes (2, 3, 4, 6, 7, 9, and 10). Chen et al. (2009) identified four QTLs for resistance to BLSB distributed on chromosomes 6, 7, and 10. In India, a F2:3 mapping population was generated using CA00106 (resistant) and CM140 (susceptible) at three geographical locations. This study led to identification of three QTLs on chromosome 6, 8, and 9 with significant epistatic interactions (Garg et al., 2009). It is important to intensify efforts to identify stable and additional sources of resistance to BLSB and improve the disease resistance of present maize hybrids.

Zea mays- Rhizoctonia solani interaction: $R$. solani belongs to a necrotrohic species complex. AG1-IA is one of the largest groups causing the most damages among all other AG groups. Little is known about the pathogenicity and virulence factors of $R$. solani. Maize pathogens have plenty of pathogenicity genes that are required for infection or for enhancing host virulence. The pathogenic capability of an organism is determined by its virulence factors. A specific interaction was governed in plant pathogen interaction that is the pathogen avr (avirulence) gene correspond with the resistance $R$-genes of the host plant. When corresponding $R$ and $a v r$ genes are present in both host and pathogen, the result is disease resistance, if either is inactive or absent, disease results (Flor, 1971; Dangl and Jones 2001).

Like other plant species, Zea mays employs a diverse array of defence mechanism that minimizes infection during interaction with pathogen. Besides pre-existing physical and chemical barriers, a variety of defence mechanisms are activated upon pathogen attack (Huang et al., 2008). During the past decades, great efforts have been devoted to understand the molecular mechanism of the plants infected by $R$. solani, such as Oryza sativa L. and Zea mays L. (Liu et al., 2009; Zhang et al., 2010). There are many catalytic enzymes involved in the $R$. solani infective response, including 
chitinase, glucanase, and phenylanine ammonia lyase (Anuratha et al., 1996; Jedidah et al., 2000; Liu et al., 2009). Furthermore, a few pathogenesis-associated genes transiently exist in maize and resisted the pathogen (Alexander et al., 1993; Datta et al., 1999; Agrawal et al., 2001; Zhu et al., 2006). Biochemical changes in many plant-pathogen interactions are accompanied by the rapid increase in phenolic compounds and related enzymes, often termed the hypersensitive response (Mondal et al., 2012). Such changes can be attributed to a variety of mechanisms of defense as exhibited by the host during pathogenesis (Jayaraj et al., 2010). Zhang et al., (2012), identified genes which are differentially expressed in maize during interaction with $R$. solani and found that 15 genes were upregulated or down-regulated in response to $\mathrm{R}$. solani infection. These genes mainly regulates transcription, protein processing, metabolism, defense, disease response and other functions. Recently, Dahima et al. (2014), estimated total phenol content, peroxidase and polyphenol oxidase content in maize germplasm affected by BLSB and concluded that higher phenol, peroxidase and polyphenol oxidase activities plays a vital role in inducing resistance against BLSB. Gao et al. (2014) conducted genome-wide gene expression profiling using Solexa sequencing, to gain insight into the transcriptome dynamics that are associated with BLSB resistance. The most differentially expressed tags were analyzed, representing, 1,476 up-regulated and 1,754 down-regulated genes, except for unknown transcripts, which were classified into 11 functional categories. The most enriched categories were those of metabolism, signal transduction and cellular transport.

Disease management: Due to ambiguity in understanding of inheritance of resistance and nonavailability of widely adapted and stable source of resistance to BLSB, control of disease by chemical and biological procedure is extremely important to minimize the destruction of crop and to prevent yield losses (Singh and Shahi, 2012).

Cultural practices: Cultural practices like stripping of the second and third leaf sheaths from the ground level at the age of 35-40 days old maize crop is effective in checking further BLSB development (Mehra et al., 2012). Inter-cropping system of maize with legumes especially with soybean effectively reduced the severity of the pathogen in soil (Kato and Incue, 1995). Maintaining the proper population level and application of cattle compost (FYM) prior to planting, helped in decrease of disease level and its subsequent spread in field (Sharma and Hembram, 1990). Selection of a welldrained field and planting on raised beds are important cultural aspects to avoid contact of excess water with seeds and faster growth of seedlings (Hooda et al., 2015). Chemical control: Many attempts have been made to control BLSB of maize through fungicides under in vitro and field condition. Different fungicides viz. Car- bendazim, Benodanil, Thiobendazole, Validamycin, Topsin M, Rhizolex, Propiconazole etc. have been tested and found to be effective in inhibiting growth of the BLSB pathogen under in vitro condition. All these fungicides except thiobendazole were effective in reducing BLSB disease severity, also under field conditions (Ahuja and Payak, 1986; Sharma and Rai, 1999). Saxena (2002), tested efficacy of chemicals (viz, Propiconazole, $0.1 \%$, and Carbendazim, 0.05\%), by applying as foliar sprays, alone or in combinations. Foliar sprays of Carbendazim showed the ineffectiveness against BLSB. On in-vitro evaluation, three often used fungicides, namely Bavistin, Rhizolex, and Thiophenate Methyl, have shown absolute control of $R$. solani mycelial growth with $100 \%$ inhibition (Sharma et al., 2002). Meena et al. (2003a), evaluated Carbendazim, kitazin and bulb extract of garlic (Allium sativum)@ $5 \%(\mathrm{w} / \mathrm{v})$ against BLSB, these fungicides and plant extract completely inhibited the mycelial growth of BLSB pathogen at $1 \mathrm{ppm}$ concentration. Rakesh et al., (2011), tested seed dressing fungicides (Bavistin $50 W P @ 2.5 \mathrm{~g} / \mathrm{kg}$ of seed, Vitavax Power $35.5 \%+$ Thiram $37.5 \%$ @ $2.5 \mathrm{~g} / \mathrm{kg}$ of seed and Thiram $50 \mathrm{WP}$ @ $2.5 \mathrm{~g} / \mathrm{kg}$ of seed) against BLSB pathogen. These fungicides has been found effective for the management of BLSB. Bavistin was found highly effective with $48.7 \%$ disease control and highest maize yield of $64.7 \mathrm{q} /$ ha over control.

Biological control: Several micro-organisms have been reported to parasitize Rhizoctonia species. These are mainly fungus of species Trichoderma, Gliocladium, and Laetisaria, bacteria (Pseudomonas sp., Bacillus subtilis), and nematodes (Aphelenchus avenae). Application of Pseudomonas fluorescens reduces disease incidence in field conditions besides improving plant growth. The biocontrol agent showed production of volatile ammonia and Hydrocyanic acid (HCN) under in vitro conditions (Sivakumar et al., 2000). Muis and Quimio (2006), developed a seed treatment formulation of the selected Bacillus subtilis to control $R$. solani in corn. Seed treatment with B. subtilis BR23 formulation supressed $R$. solani in microplots and increased grain yield by $27 \%$ compared to that of the control capton with 14.4 per cent. Madhavi et al. (2011), used Pseudomonas flurorescens aganist $R$. solani caused BLSB of maize under in-vitro condition. The results showed that Pseudomonads have significantly inhibited the mycelial growth and sclerotial germination of $R$. solani ranging from $48 \%-92 \%$ and $29 \%$ $-87 \%$ respectively over check. Trichoderma sp. found to be an effective biocontol agent, provided as high as $68 \%$ of inhibition of the mycelia of $R$. solani, under in vitro conditions, compared to the control of BLSB (Sharma et al., 2002). Volatile compounds released by $T$. harzianum supress both growth and sclerotial formation of $R$. solani, inhibited $80 \%$ and $34 \%$ respectively followed by $T$. viride which inhibited $70 \%$ 
growth and $26 \%$ sclerotial formation (Meena et al., 2003b). Trichoderma hyphae coiled around $R$. solani hyphae and subsequently caused the cell wall lysis (Yobo et al., 2004). Khan and Sinha (2007), reported $T$. harzianum and its volatile compound inhibited $R$. solani followed by $T$. viride in dual culture techniques. Sahar et al. (2009), also reported that T. hamatum showed highest reduction in the growth of $R$. solani followed by $B$. subtilis, while it was less effective against $M$. phaseolina and $F$. solani.

Integrated disease management: Integrated disease management (IDM) which covers physical, cultural, chemical, biological and resistance hybrids/varieties, are required for the control of BLSB. This strategy emphasizes prudent use of chemicals in combination with other management practices for maximizing yield with minimum environmental hazards. Dalmacio et al. (1990), conducted three experiments on the mechanical, chemical and biological control of BLSB. In case of mechanical control, the de-leafing of basal portion of maize plants proved to be effective in controlling the upward spread of lesion. Among the chemicals and biological agents, Validamycin gave the best control followed by T. harzianum. Akhtar et al. (2010), concluded that management of BLSB can be achieved by integrating soil application of $T$. harzianum precolonized farmyard manure (FYM) with foliar application of carbendazim. In an IDM approach, Singh and Singh (2011) found best performance of Validamycin $(0.25 \%)$ and $T$. viride as foliar spray than the fungicides like Tilt $(0.15 \%)$ and Bavistin $(0.1 \%)$ and bioagent $P$. florescence which contributed higher maize grain yield over check. Carbendazim, neem oil and $T$. harzianum as seed treatment (ST) and combinations of sprays with ST were found effective for managing BLSB of maize in field condition (Bunker et al., 2012). Rani et al. (2013), examined fungicides and biocontrol agents viz. benomyl, carbendazim, thiram, T. viride, P. fluorescens and B. subtilis as seed and soil treatments against BLSB. Among all the treatments carbendazim and $T$. viride showed $37.93 \%$ and $41.9 \%$ respectively, reduction in BLSB disease severity.

\section{Conclusion}

The present study concluded that management of maize pathogens is considered very important in the present scenario because the BLSB caused by $R$. solani is most prevalent and serious limiting factors for the successful cultivation of maize worldwide. Studies revealed that none of disease management strategies is absolutely effective against BLSB. Variability within pathogen should be considered for screening and breeding for resistance, or while testing sensitivity of the pathogen towards different fungicides. The integrated management approaches evolved particularly in the present changing climate would provide sustainable management of BLSB. Moreover, inheritance pattern of BLSB resistance in maize verities/hybrids through conventional and/or biotechnological approaches. Additionally, progresses made in the "omics" field will revolutionize the possibilities for improving pathogen identification and investigating host-pathogen interaction, epidemiology and development of novel disease management practices. All these information should lead to more efficient management of this menacing disease.

\section{REFERENCES}

Agrawal, G.K., Rakwal, R., Jwa, N.S. and Agrawal, V.P. (2001). Signalling molecules and blast pathogen attack activates rice OsPR1a and OsPR1b genes: A model illustrating components participating during defence/stress response. Plant Physiol. Biochem., 39: 1095-1103.

Ahuja, S.C. and Payak, M. M. (1985). Comparative biology, pathology and karyology of rice and maize isolates of Rhizoctonia solani f. sp. sasakii. Int. Rice Res. Newsl.10: 5-6.

Ahuja, S.C. and Payak, M. M. (1986). In vitro response of maize and rice isolates of Rhizoctonia solani to antibiotic and fungi-toxicants. Int. Rice Res. Newsl.11: 16

Ahuja, S.C. and Payak, M. M. (1988). Banded leaf and Sheath blight of maize. In: Agnihotri, V.P.; Sarbhoy. A.K. and Kumar, D. (eds.) Perspectives in Mycology and Plant Pathology, Malhotra Publishing House, New Delhi, India. pp. $1: 186$.

Ahuja, S.C. and Payak, M.M. (1982). Symptoms and signs of banded leaf and sheath blight in maize. Phytopapasitica 10: $41-49$

Akhtar, J., Jha, V.K. and Lal, H.C. (2009). Occurrence of Banded Leaf and Sheath blight of Maize in Jharkhand with Reference to Diversity in Rhizoctonia solani. Asian J. Agri. Sci. 1 (2): 32-35.

Akhtar, J., Kumar, V., Tiu, K.R. and Lal, H.C. (2010). Integrated management of banded leaf and sheath blight disease of maize. Plant Dis. Res. 25 (1): 35-38.

Alexander, D., Goodman, R.M., Gut-Rella, M., Glascock, C., Weymann, K., Friedrich, L., Maddox, D., Ahl-Goy, P., Luntz, T. and Ward, E. (1993). Increased tolerance to two oomycete pathogens in transgenic tobacco expressing pathogenesis-related protein 1a. Proc. Natl. Acad. Sci. USA. 90: 7327-7331.

Anderson, N. A. (1982). The genetics and pathology of Rhizoctonia solani, Annu. Rev. Phtopathol. 20, 329-344.

Anuratha, C.S., Zen, K.C., Cole, K.C., Muthukrishnan, S. and Mew, T. (1996). Induction of chitinases and $\beta-1,3-$ glucanases in Rhizoctonia solani-infected rice plants: Isolation of an infection-related chitinase cDNA clone. Physiol. Planta., 97(1): 39-46.

Asea, G., Vivek, B.S., Lipps, P.E. and Pratt, R.C. (2012). Genetic gain and cost efficiency of marker-assisted selection of maize for improved resistance to multiple foliar pathogens. Mol. Breeding 29: 515-527.

Back, M.A., Haydock, P.P.J. and Jenkinson, P. (2002). Disease complexes involving plant parasitic nematodes and soilborne pathogens. Plant Pathol. 51: 683-697.

Baker, C.J. and Bateman, D.F. (1978). Cutin degradation by the plant pathogenic fungi. Phytopathol. 68: 1577-1584.

Banniza, S. and Rutherford, M.A. (2001). Diversity of isolates of Rhizoctonia solani AG1-IA and their relationship to 
other anastomosis groups based on pectic zymograms and molecular analysis. Mycol. Res. 105: 33-40.

Banniza, S., Sy, A.A., Bridge, P.D., Simons, S.A. and Holderness, M. (1999). Characterization of populations of Rhizoctonia solani in paddy rice fields in Cote d' Ivoire. Phytopathol. 89: 414-420.

Baruah, P. and Lal, S. (1981). Host range of Rhizoctonia solani $\mathrm{f}$. sp. sasakii, then incitant of banded sclerotial disease of maize. Indian Phytopathol. 34: 494-496.

Bernardes-De-Assis, J., Storari, M., Zala, M., Wang, W.X., Jiang, D.H., Li, S.D., Jin, M., McDonald, B.A. and Ceresini, P.C. (2009). Genetic structure of populations of the rice-infecting pathogen Rhizoctonia solani AG1IA from china. Phytopathol.,99:1090-1099

Bertagnolli, B.L. Dal Soglio, F.H. and Sinclair, J.B. (1996). Extracellular enzyme profiles of the fungal pathogen Rhizoctonia solani isolate 2B-12 and two antagonists, Bacillus megaterium strain B153-2-2 and Trichoderma harzianum isolate Th008. I. Possible correlations with inhibition of growth and biocontrol. Physiol. Mol. Plant Path. 48: 145-160.

Bertus, L.S. (1927). Year book. Department of Agriculture, Ceylon, pp 44-46.

Binder, M., Hibbett, D., Larsson, K., Larsson, E., Langer, E. and Langer, G. (2005). The phylogenetic distribution of resupinate forms across the major clades of mushroomforming fungi (Homobasidiomycetes). Syst. Biodivers.,3 (2): $1-45$

Buddemeyer, J.G., Buttner, M.E., Fuhrer, I. and Petersen, J. (2004). Genetic variation in susceptibility of maize to Rhizoctonia solani (AG 2-IIIB) symptoms and damage under field conditions in Germany Ltd. J. Plant Dis. Protec. 111(6): 521-533.

Bunker, R.N., Trivedi, A. and Mathur, K. (2012). Integrated management of banded leaf and sheath blight of maize caused by Rhizoctonia solani f. sp. sasakii. J. Mycol. Plant Pathol. 42:367-371.

Caesar, A.J., Caesar, T. and Maathuis, M.H. (2010). Pathogenicity, characterization and comparative virulence of Rhizoctonia spp. from insect-galled roots of Lepidium draba in Europe. Biol. Control. 52: 140-144.

Campbell, M.A., Fitzgerald, H.A. and Ronald, P.C. (2002) Engineering pathogen resistance in crop plants. Transgenic Res. 11: 599-613.

Charoensopharat, K., Aukkanit, N., Thanonkeo, S., Saksirirat, W., Thanonkeo, P. and Akiyana, K. (2008). Targeted disruption of a $\mathrm{G}$ protein alpha subunit gene results in reduction growth and pathogenicity in Rhizoctonia solani. World J. Microb. Biot. 24: 345-351.

Chen, J., Tang, C., Gao, Z., Xue, C., Niu, X. and Song, Z. (2000). On penetration process of sheath blight pathogen in maize. J. Shenyang Agric. Univ. 31: 503-506.

Chen, G.P., Tan, H., Zheng, D.B., Yang, L.T. and Li, Y.R. (2009). QTL mapping of resistance to banded leaf and sheath blight in maize. Southwest China J. Agri. Sci. 22: 950-955.

Chikara, R.K., Malik, V. and Kumar, U. (2015). Identification of RAPD based genetic variability in Rhizoctonia solani isolates from Northern India. Internatl. J. Recent Biotechnol. 3(2): 25-30.

Cubeta, M.A., Dean, R.A., Thomas, E., Bayman, P., Jabaji, S., Neate, S., et al. (2009). Rhizoctoniz solani genome project: providing insight into a link between beneficial and plant pathogenic fungi. Phytopathol., 99: S166.

Cubeta, M.A., Thomas,E., Dean, R.A., Jabaji, S., Neate, S.M., Tavantzis, S., Toda, T., Vilgalys, R., Bharathan, N., Fedorova-Abrams, N., Pakala, S.B., Pakala, S.M., Zafar, N., Joardar, V., Losada, L. and Nierman, W.C. (2014). Draft genome sequence of the plant-pathogenic soil fungus Rhizoctonia solani anastomosis group 3 stari Rhs 1 AP. Genome Announc. 2(5): e1072-14.

Dahima, V., Sharma, S.S., Khokhar, M.K. and Hooda, K.S. (2014). Post-infectional biochemical changes in maize leaves affected by banded leaf and sheath blight disease. Indian Phytopathol. 67 (4): 370-373.

Dalmacio, S.C., Lozano, G.P., De, L.P. and Candole, B.L. (1990). Mechanical, biological and chemical control of banded leaf and sheath blight on maize caused by Rhizoctonia solani [Philippines]. Plant Dis. Res., 20:133-156

Dangl, J.L. and Jones, J.D. (2001). Plant pathogens and integrated defense responses to infection. Nature 411: 82633.

Datta, K., Velazhahan, R., Oliva, N., Ona, I., Mew, T., Khush, G.S., Muthukrishnan, S., Datta, S.K. (1999). Over-expression of the cloned rice thaumatin-like protein (PR-5) gene in transgenic rice plants enhances environmental friendly resistance to Rhizoctonia solani causing sheath blight disease. Theor. Appl. Genet., 98: 1138-1145.

Demirci, E. and Döken, M.T. (1998). Host penetration and infection by the Anastomosis groups Rhizoctonia solani Kühn isolated from potatoes. Turk. J. Agri. For. 22: 609 $-613$.

Dodman, R.L. and Flentje, N.T. (1970). The mechanism and physiology of plant penetration by Rhizoctonia solani. In: Parmeter, J.R. (ed) Rhizoctonia solani, Biology and Pathology, University of California Press, Berkeley/Los Angeles/London, pp 149-160.

Fang, X., Finnegan, P.M. and Barbetti, M.J. (2013). Wide variation in virulence and genetic diversity of binucleate Rhizoctonia isolates associated with root rot of strawberry in Western Australia. PloS One, 8(2): e55877.

FAO (2015). FAOSTAT, Production. Accessed on February 23, 2016. http://faostat.fao.org/site/567/ DesktopDefault.aspx?PageID=567\#ancor.

Fenille, R.C., Ciampi, M.B., Kuramae, E.E. and Souza, N.L. (2003). Identification of Rhizoctonia solani associated with soybean in Brazil by rDNA-ITS sequences. Fitopatologia Brasileira 28: 413-9.

Fiers, M., Edel-Hermann, V., Hěraud, C., Gautheron, N., Chatot, C., Hingrat, Y.L., Bouchek-Mechiche, K. and Steinberg, C. (2011). Genetic diversity of Rhizoctonia solani associated with potato tubers in France. Mycologia 103(6): 1230-1244.

Flor, H.H. (1971). Current status of the gene-for-gene concept. Annu. Rev. Phytopathol. 9: 275-296.

Gad, M.A., Ibrahim, N.A. and Bora, T.C. (2013). RAPD Based Genetic Variation in Rhizoctonia sp. in India. $J$. Biochem. Chem. Res. 30(1): 67-75.

Gao, J., Chen, Z., Luo, M., Peng, H., Lin, H., Qin, C., Yuan, G., Shen, Y., Ding, H., Zhao, M., Pan, G. and Zhang, Z. (2014). Genome expression profile analysis of the maize sheath in response to inoculation to $R$. solani. Mol. Biol. Rep. 41: 2471-2483.

Gao, S. and Nuss, D.L. (1996). Distinct roles for two G pro- 
tein a subunits in fungal virulence, morphology, and reproduction revealed by targeted gene disruption. Proc. Natl. Acad. Sci. USA, 93: 14122-14127.

Garg, A., Prasanna, B.M. and Sharma, R.C. (2009). Genetic analysis and mapping of QTLs for resistance to banded leaf and sheath blight (Rhizoctonia solani f. sp. sasakii) in maize. In: Proceedings of $10^{\text {th }}$ Asian regional maize workshop (October 20-23, 2008, Makassar, Indonesia). CIMMYT, Mexico DF (in press).

Gonzãlez-Garcia, V., Portal Onco, M.A. and Rubio Susan, V. (2006). Review: biology and systematics of the genus Rhizoctonia. Spanish J. Agri. Res. 4(1): 55-79.

Gonzalez-Vera, A.D., Bernardes-De-Assis, J., Zala, M., McDonald, B.A. Correa-Victoria, F., Graterol-Matute, E.J. et al. (2010). Divergence between sympatric rice- and maize infecting populations of Rhizoctonia solani AG1-IA from Latin America. Phytopathol. 100: 172-182

Hafiz, A. (1986). Plant Disease. Pakistan Agricultural Research Council, Islamabad, pp 93-102

Hane, J.K., Anderson, J.P., Williams, A.H., Sperscneider, J. and Singh, K.B. (2014). Genome Sequencing and Comparative Genomics of the Broad Host-Range Pathogen Rhizoctonia solani AG8. PLoS Genet. 10(5): e10042281

Hooda, K.S., Khokhar, M.K., Parmar, H., Gogoi, R., Joshi, D., Sharma, S.S. and Yadav, O.P. (2015). Banded Leaf and Sheath Blight of Maize: Historical Perspectives, Current Status and Future Direction. Proc. Natl. Acad. Sci., India, Sect. B Biol. Sci., 1-12

Huang, M., Tan, J., Yang, J. and Yang, K. (2007). Research advances on Banded leaf and Sheath Blight of maize. Southwest China J. Agric. Sci. 8: 129-137

Huang, S.W., Wang, L., Wang, Q.Y., Tang, S.Q., Chen, H.Z. and Zhu, D.F. (2008). Rice sheath blight pathogen impacts the activities of disease resistance-related enzymes in leaves of different rice verities. Chinese J. Rice Sci. 22: 219-222.

Izhar, T. and Chakraborty, M. (2013). Genetic analysis of banded leaf and sheath blight resistance (Rhizoctonia solani) in maize. J. Pharmacogn. Phytochem. 1: 1-5

Jain, S., Akiyama, K., Mae, K., Ohguchi, T. and Takata, R. (2002). Targeted disruption of a G protein $\alpha$ subunit gene results in reduced pathogenicity in Fusarium oxysporum. Curr. Genet. 41: 407-413.

Jayaraj, J., Ranganathan, B., Ramalingam, R., Muthukrishnan, S. and Rethinasamy, V. (2010). Oxalic acid-induced resistance to Rhizoctonia solani in rice is associated with induction of phenolics, peroxidase and pathogenesis-related proteins. J. Plant Interaction 5: 147-157.

Jayasinghe, C.K., Wijayaratne, S.C.P. and Fernando, T.H.P.S. (2004). Characterization of cell wall degrading enzymes of Thanatephorus cucumeris. Mycopathologia 157: 73-79

Jedidah, D., Kikuo, W. and Akihiro, N. (2000). Invertase activities in sheath-blight infected rice selection lines and fungus culture filtrates. J. Gen. Plant Pathol., 66 (3): 202-205

Joshi, P.K., Singh, N.P., Singh, N.N., Gerpacio, R.V. and Pingali, P.L. (2005). Maize in India: production systems, constraints, and research priorities. International Maize and Wheat Improvement Centre (CIMMYT), Mexico. D.F

Kato, A. and Incue, Y. (1995). Resistance to banded leaf and sheath blight (Rhizoctonia solani Kühn) after fall of lower sheaths in maize (Zea mays L). Bulletin of the National Grass/and Research Institute (Japan) 51:1-5.

Keijer, J. (1996a). The initial steps of the infection process in Rhizoctonia solani. In: Sneh, B., Jabaji-Hare, S., Neate, S. and Dijst, G. (eds) Rhizoctonia species: Taxonomy, Molecular Biology, Ecology, Pathology and Disease control. Kluwer Academic Publishers, The Netherlands. pp 149-162.

Keijer, J., Houterman, P.M., Dullemans, A.M. and Korsman, M.G. (1996b). Heterogeneity in electrophoretic karyotype within and between anastomosis groups of Rhizoctonia solani. Mycol. Res. 100: 789-797.

Khan, A.A. and Sinha, A.P. (2007). Screening of Trichoderma spp. against Rhizoctonia solani the causal agent of rice sheath blight. Indian Phytopathol. 60(4): 450-456.

Khodayari, M., Safaie, N. and Shamsbakhsh, M. (2009). Genetic Diversity of Iranian AG1-IA Isolates of Rhizoctonia solani, the Cause of Rice Sheath Blight, Using Morphological and Molecular Markers. J. Phytopathol. 157: 708-714.

Knight, B.C. and Bunil, W.D. (1964). Sharp eye spots of maize. Plant Pathol. 13: 138.

Kumar, R. and Singh, I.S. (2002). Inheritance of resistance to banded leaf and sheath blight (Rhizoctonia solani $\mathrm{f}$. sp. sasakii) of maize (Zea mays L.). Proceeding of the $8^{\text {th }}$ ASIAN Regional Maize Workshop, Bangkok, Thailand, pp 356-365.

Lal, S., Baruah, P. and Butchaiah, K. (1980). Assessment of yield losses in maize cultivars due to banded leaf sclerotial disease. Indian Phytopathol. 29: 129-132.

Lal, S., Butchaiah, K. and Baruah, P. (1985). Comparative efficacy of some fungicides and antibiotics in control of banded sclerotial disease of maize. Pesticides 19: 17-19.

Li, L., Wright, S.J., Krystofova, S., Park, G. and Borkovich, K.A. (2007). Heterotrimeric $G$ protein signalling in filamentous fungi. Annu. Rev. Microbiol. 61: 423-452.

Li, L., YongYi, M., ZhiMing, Z., PengFei, L., GuangTang, P. and MaoJun, Z. (2009). Functional effects of different defence enzymes on banded leaf and sheath blight of maize. J. Maize Sci. 17: 99-102.

Lin, H.J., Tan, D.F., Zhang, Z.M., Lan, H., Gao, S.B., Rong, T.Z. and Pan, G.T. (2008). Analysis of digenic epistatic and QTL $\times$ environment interaction for resistance to banded leaf and sheath blight in maize (Zea mays L.). Int. J. Agri. Biol. 10: 605-611

Linde, C.C., Zala, M., Paulraj, R.S.D., McDonald, B.A. and Gnanamanickam, S. (2005). Population structure of the rice sheath blight pathogen Rhizoctonia solani AG1-IA from India. Eur. J. Plant Pathol. 112: 113-121.

Liu, L., Ma, Y.Y., Zhang, Z.M., Pan, G.T. and Zhao, M.J. (2009). cDNA-AFLP analysis of Rhizoctonia solani AG1-IA-induced maize differential gene expression. Acta. Phytopathol. Sinica., 39(4): 385-391.

Liu, L., Zhang, Z., Zhao, .M, Wang, J., Lin, H., Shen, Y. and Pan, G. (2011). Molecular cloning and characterization of pathogenesis-related protein 5 in Zea mays and its antifungal activity against Rhizoctonia solani. Afr. J. Biotechnol. 10: 19286-19293.

Liu, Z.L. and Sinclair, J.B. (1993b). Differentiation of intraspecific group within anastomosis group 1 of Rhizoctonia solani using ribosomal DNA internal transcribed spacer and isozyme comparison. Canadian J. Plant Pathol. 15: 271-280. 
Liu, Z.L. and Sinclair, J.B. (1993a). Differentiation of intraspecific groups within anastomosis group I of Rhizoctonia solani species complex. Mycologia 85: 797-800.

Lu, Y.L, Xu, J., Yuan, Z.M., Hao, Z.F. Xie, C.X., Li, X.H., Shah, T., Lan, H., Zhang, S.H., Rong, T.Z. and $\mathrm{Xu}$, Y.B. (2012). Cooperative LD mapping using single SNPs and haplotypes identifies QTL for plant height and biomass as secondary traits of drought tolerance in maize. Mol. Breeding 30: 407-418.

Madhavi, G.B., Bhattiprolu, S.L., Bharathi, S., Reddy, V.C. and Ankaiah, R. (2011). Studies on the management of banded leaf and sheath blight disease of maize (Rhizoctoniz solani f. sp. sasakii) using fluorescent Pseudomonads. In: Proc. $2^{\text {nd }}$ Asian PGPR Conference, Beijing P.R. China, pp 567-576.

Marshall, D.S. and Rush, M.C. (1980). Relation between infection by Rhizoctonia solani and $R$. oryzae and disease severity in rice. Phytopathol. 70: 941-946.

Matsuyama, N., Moromizato, Z., Ogoshi, A. and Wakimoto, S. (1978). Grouping Rhizoctonia solani with nonspecific esterase zymogram. Ann. Phytopathol. Soc. Jpn., 44: 652-658

Meena, R., Rathore, L. and KusumMathur, R.S. (2003a). Evaluation of fungicides and plant extracts against banded leaf and sheath blight of maize. Indian J. Plant Protec. 31 (1): 94-97

Meena, R., Rathore, L. and KusumMathur, R.S. (2003b). Efficacy of biocontrol agents against Rhizoctonia solani f. sp. sasakii causing banded leaf and sheath blight of maize. J. Mycol. Plant Pathol. 33(2): 310-312.

Mehra, R., Kamboj, M.C., Mehla, J.C., Madan, L. and Chand, M. (2012). Status of maize diseases and their management in Haryana. In: Proceedings of national seminar on sustainable agriculture and food security: challenges in changing climate. CCS HAU, Hisar, pp 217. 27-28 Mar 2012.

Mondal, A., Dutta, S., Nandi, S., Das, S. and Chaudhuri, S. (2012). Changes in defence-related enzymes in rice responding to challenges by Rhizoctonia solani. Arch. Phytopath. Plant Protec. 45: 1840-1851.

Muis, A. and Quimio, A.J. (2006). Biological control of banded leaf and sheath blight disease (Rhizoctonia solani Kühn) in corn with formulated Bacillus subtilis BR23. Indonesian J. Agri. Sci. 7(1): 1-7.

Neeraja, C.N., Shenoy, V.V., Reddy, C.S. and Sharma, N.P. (2000a). Isozyme polymorphism and virulence of Indian isolates of the rice sheath blight fungus. Mycopathologia 159: 101-108.

Neeraja, C.N., Vijayabhanu, N., Shenoy, V.V., Reddy, C.S. and Sharma, N.P. (2000b). RAPD analysis of Indian isolates of rice sheath blight fungus Rhizoctonia solani. J. Plant Biochem. Biotechnol. 11: 43-48

Neves, S.R., Ram, P.T. and Iyengar, R. (2002). G protein pathways. Science 296: 1636-1639

Nuss, E.T. and Tanumihardjo, S.A. (2010). Maize: a paramount stable crop in the context of global nutrition Compr. Rev. Food Sci. Food Saf. 9:417-436.

Ogoshi, A. (1975). Grouping of Rhizoctonia solani Kühn and their perfect stages. Rev. Plant Prot. Res. Japan 8: 93-103

Ogoshi, A. (1987). Ecology and pathogenicity of anastomosis and interspecific groups of Rhizoctonia solani Kühn. Annu. Rev. Phytopathol. 25: 125-143

Parmeter, J.R. (1970). Rhizoctoniz solani: Biology and Pathology. University of California Press, USA, pp 255
Parmeter, J.R., Sherwood, R.T. and Platt, W.D. (1969). Anastomosis grouping among isolates of Thanatephorus cucumeris. Phytopathol. 59: 1270-1278.

Peltonen, S. (1995). Comparison of xylanases production by fungal pathogens of barley with special preference to Bipolaris sorokiniana. Mycol. Res. 99: 717-723

Rakesh, D., Guleria, S.K. and Thakur, D.R. (2011). Evaluation of seed dressing fungicides for the management of banded leaf \& sheath blight of maize. Plant Dis. Res. 26 (2): 169

Rani, V.D., Reddy, P.N. and Devi, G.U. (2013). Banded leaf and sheath blight of maize incited by Rhizoctonia solani f. sp. sasakii and its management- A review. Int. J. Appl. Biol. Pharma Tech. 4: 52-6.

Regenfelder, E., Spellig, T., Hartmann, A., Lauenstein, S., Bolker, M. and Kahmann, R. (1997). G protein in Ustilago mayis: transmission of multiple signals. EMBO Journal 16: 1934-1942.

Rosewich, U.L., Pettway, R.E., McDonald, B.A. and Kistler, H.C. (1999). High level of gene flow and heterozygote excess characterize Rhizoctonia solani AG-1 IA (Thanatephorus cucumeris) from Texas. Fungal Genet. Biol. 28: 148-159.

Sahar, A., El-Sayed, Rania, Z., El-Shennawy and Tolba, A.F. (2009). Efficacy of chemical and biological treatments for controlling soil borne pathogens of soybean. J Agri. Sci. 17(1): 163-173.

Saxena, S. C. (1997). Banded leaf and Sheath blight of maize. In: Agnihotri, V.P.; Sarbhoy. A.K. and Singh, D.V (eds) Management of threatening plant diseases of national importance. Malhotra Publishing House, New Delhi, pp 31-50.

Saxena, S.C. (2002). Bio-Intensive Integrated Disease Management of Banded Leaf \& Sheath Blight of Maize. In: Proc. of the $8^{\text {th }}$ Asian Regional Maize Workshop, Bangkok, Thailand, pp 380-390.

Sharma, R.C (2005). Banded leaf and sheath blight (Rhizoctona solani f. sp. sasakii) of maize. In: Zaidi P.H. and Singh, N.N. (eds), Stresses of maize in Tropics, pp 159-171.

Sharma, R.C. and Hembram, D. (1990). Leaf stripping: a method to control banded leaf and sheath blight of maize. Current Sci., 59:745-746.

ISharma, R.C. and Rai, S.N. (1999). Chemical control of banded leaf and sheath blight of maize. Indian Phytopathol. 52 (1): 94-95.

Sharma, R.C., Vasal, S.K., Gonzalez, F., Batsa, B.K. and Singh, N.N. (2002). Redressal of banded leaf and sheath blight of maize through breeding, chemical and biocontrol agents, pp. 391-397. In: Proceed of the $8^{\text {th }}$ Asian Regional Maize Workshop; New Technologies for the New Millennium, Bangkok.

Sharma, R.R. (1999). Pathological and biological attribute of Rhizoctonia solani f. sp. sasakii Exner, the causal organism of banded leaf and sheath blight of maize. M. Sc. Thesis, RAU, RCA, Udaipur.

Singh, A. and Shahi, J.P. (2012). Banded leaf and sheath blight: an emerging disease of maize (Zea mays L.). Maydica 57: 215-219.

Singh, A. and Singh, D. (2011). Integrated disease management strategy of banded leaf and sheath blight of maize. Plant Dis. Res., 26:192.

Singh, B.M and Sharma, Y.R. (1976). Evaluation of maize 
germplasm to banded sclerotial disease and assessment of yield loss. Indian Phytopathol. 29: 129-132.

Sivakumar, G., Sharma, R.C. and Rai, S.N. (2000). Biocontrol of banded leaf and sheath blight of maize by peat based Pseudomonas fluorescence formulation. Indian Phytopathol. 53 (2): 190-192.

Sneh, B., Burpee, L., and Ogoshi, A. (1991). Identification of Rhizoctonia species. St. Paul: The American Phytopathological Society.

Stevens Johnk, J. and Jones, R.K. (1994). Comparison of whole cell fatty acid compositions in intra-specific groups of Rhizoctonia solani AG-1. Phytopathol.84: 271-275.

Susheela, K. and Reddy, C.S. (2013). Variability in Rhizoctonia solani (AG1-IA) isolates causing sheath blight of rice in India. Indian Phytopathol. 64(4): 341-350.

Taheri, P., Gnanamanickam, S. and Höfte, M. (2007). Characterization, genetic structure, and pathogenicity of Rhizoctonia spp. associated with rice sheath diseases in India. Phytopathol.97: 373-383.

Tang, H.T., Rong, T.Z. and Yang, J.P. (2004). Research advance on sheath blight (Zea mays L.) in maize. $J$. Maize Sci., 12: 93.

Trivedi, A. and Rathore, R.S. (2006). New grass hosts for Banded leaf and sheath blight of maize. Indian Phytopathol. 59: 253-254.

Vimla, B., Mukherjee, B.K and Ahuja, V.P. (1988). Combining ability analysis for resistance to banded leaf and sheath blight of maize. Indian J. Genet. 48: 75-79.

Wang, L., Liu, L.M, Hou, Y.X., Li, L. and Huang, S.W. (2015). Pathotypic and genetic diversity in the population of Rhizoctonia solani AG1-IA causing rice sheath blight in China. Plant Pathol. 64: 718-728.

Wendland, J. (2001). Comparison of morphogenetic networks of filamentous fungi and yeast. Fungal Genet. Biol. 34: 985-990

Wibberg, D., Jelonek, L., Rupp, O., Hennig, M., Eikmeyer, F., Goesmann, A., Hartmann, A., Borriss, R., Grosch, R., Pühler, A. and Schlüter, A. (2013). Establishment and interpretation of the genome sequence of the phytopathogenic fungus Rhizoctonia solani AG-IB isolate 7/3/14. J. Biotechnol. 167: 142-155.

Wiltshire, S.P. (1956). Plant Disease in British Colonial Dependencies; A half-yearly report. F.A.O. Plant Protection Bulletin 5: 66.

Wu, W., Huang, J., Cui, K., Nie, L., Wang, Q., Yang, F., Shah, F., Yao, F., and Peng, S. (2012). Sheath blight reduces stem breaking resistance and increases lodging susceptibility of rice plants. Field Crops Res., 128: 101-108.

Xia, H.B., Wu, E.Y. and Yu, J.F. (2008). The anastomosis groups of the corn sheath blight pathogen Rhizoctonia spp. in huanghuai plain and haihe plain of China. Mycosystema, 27 : 360-367.

Yobo, K.S., Laing, M.D., Hunter, C.H. and Morris, M.J. (2004). Biological control of Rhizoctonia solani by two Trichoderma species isolated from South African composted soil. S. Afr. J. Plant Soil, 88: 265-268.

Zhang Z, Li W, Zhao M, Rong T, Pan G, Jeffers DP, Zhang S (2006) Quantitative trait loci for resistance to banded leaf and sheath blight in maize. Crop Sci. 46:1039-1045.

Zhang Z, Liu L, Lin H, Yuan G, Zeng X, Shen Y, Zhao M, Zhao Q, Pan G (2012) Identification of genes differentially expressed in maize (Zea mays L.) during Rhizoctonia Solani Kühn infection by suppression subtractive hybridization. Afr. J. Biotechnol. 11:2827-2838.

Zhang, Z.M., Liu, L., Wang, J., Zhao, M.J. and Pan, G.T. (2010). Cloning and characterization of a senescence a ssociated protein gene (ZmSAP) induced by Rhizoctonia solani in maize. Acta. Phytopathol. Sinica., 40(4): 373-380.

Zhao, M.J., Zhang, Z.M., Zhang, S.H., Li, W., Jeffers, D.P., Rong, T.Z. and Pan, G.T. (2006). Quantitative trait loci for resistance to banded leaf and sheath blight in maize. Crop Sci. 46: 1039-1045.

Zheng, A., Lin, R., Zhang, D., Qin, P., Xu, L., Ai, P., Ding, L., Wang, Y., Chen, Y., Liu, Y., Sun, Z., Feng, H., Liang, X., Fu, R., Tang, C., Li, Q., Zhang, J., Xie, Z., Deng, Q., Li, S., Wang, S., Zhu, J., Wang, L., Liu, H. and Li, P. (2013). The evolution and pathogenic mechanisms of the rice sheath blight pathogen. Nature Communic. 4: 1424.

Zhou, S. Y., Liu, Y., Zhang, M., Li, B.D., Chen, X.J., and Liang, W. X. (2016). Comparison of the virulence and cognate virulence factors of multinucleate, binucleate and uninucleate Rhizoctonia isolates, causing sheath blight on maize plants. Eur. J. Plant Pathol. 144: 235-243.

Zhou, S.Y., Ji, Z., Zhao, C.D., Liu, Y. and Li, B.D. (2012). Anastomosis grouping and genetic diversity of miaze pathogen Rhizoctonia solani in Shandong. Mycosystema, 31: 31-39.

Zhou, S.Y., Zhang, M., Liu, Y., Chen, X.J., Ji, Z., Guo, Z.J., and Li, B.D. (2015). A uninucleate Rhizoctonia sp. from maize plant with ITS heterogeneity and hypersensitive to abiotic stresses. Eur. J. Plant Pathol. 142: 397-401.

Zhu, T., Song, F. and Zheng, Z. (2006). Molecular characterization of the rice pathogenesis-related protein, OsPR $-4 \mathrm{~b}$, and its antifungal activity against Rhizoctonia solani. J. Phytopath., 154: 378-384. 